\title{
Molecular epidemiology of prostate cancer: androgens and polymorphisms in androgen-related genes
}

\author{
Christos Ntais, Anastasia Polycarpou and Agathocles Tsatsoulis \\ Division of Endocrinology, Department of Internal Medicine, University of Ioannina School of Medicine, Ioannina 45110, Greece \\ (Correspondence should be addressed to A Tsatsoulis; Email: atsatsou@cc.uoi.gr)
}

\begin{abstract}
In most western countries prostate cancer is the most commonly diagnosed non-skin cancer in men. Despite its high morbidity and mortality the etiology of prostate cancer remains obscure. The involvement of androgens has been examined extensively in prostate carcinogenesis but the results of most epidemiological studies remain inconclusive. This review focuses on current perspectives of androgen levels and polymorphisms in androgen-related genes. Racial differences in genetic polymorphisms that have a role in the biosynthesis and metabolism of androgens may partly account for racial differences in prostate cancer risk. Reasons are also given for inconsistent results in molecular epidemiological studies and insights and directions for future research are discussed. The development of a polygenic model for prostate cancer, incorporating multiple loci from the individual genes, may maximize the chance of identifying individuals with high-risk genotypes, resulting in better preventive, diagnostic, and therapeutic strategies.
\end{abstract}

European Journal of Endocrinology 149 469-477

\section{Introduction}

Prostate cancer is the most commonly diagnosed malignancy and the second leading cause of death as a result of cancer in men in the United States and many other western countries. There is a large variation in prostate cancer incidence rates between racial/ethnic groups, highest among Africans, intermediate among Caucasians, and lowest among Asians (1). Although the reasons for this large disparity in risk are mostly unclear, population differences in androgen levels and dietary factors have been implicated as possible explanations.

Steroid hormones, particularly androgens, appear to play a major role in the development of prostate cancer, but their precise role is not clear $(2,3)$. Prostate cancer regresses after anti-androgen therapy, and administration of testosterone induces prostate tumors in laboratory animals $(4,5)$. However, epidemiological studies addressing the role of androgens in prostate cancer have produced conflicting results. The search for genetic markers of prostate cancer susceptibility has revealed an increasing number of genetic polymorphisms that may have a role in the metabolism of testosterone and other androgens.

\section{Biosynthesis and metabolism of androgens}

Androgens are steroid hormones that induce the differentiation and maturation of the male reproductive organs and the development of male secondary sex characteristics. In men, androgens are formed in the testes and the adrenal gland whereas they are metabolized in the prostate and skin. Androgen production is regulated by the hypothalamic-pituitary-gonadal axis. Gonadotropin-releasing hormone is secreted by the hypothalamus in pulses, thus stimulating luteinizing hormone (LH) secretion from the pituitary gland. $\mathrm{LH}$ acts on Leydig cells in the testis to induce androgen production.

Testosterone, the major male androgen in the circulation, and dihydrotestosterone (DHT), the principal androgen in tissue and the most potent androgen, are the two most important androgens in adult males. In blood, roughly $44 \%$ of testosterone is bound with high affinity to sex hormone-binding globulin, 54\% with low affinity to albumin, and only $1-2 \%$ of testosterone exists in a free, bioavailable state. About $25 \%$ of the DHT in the circulation is secreted by the testes, while most arises from conversion of testosterone in peripheral tissue in a reaction catalyzed by the 


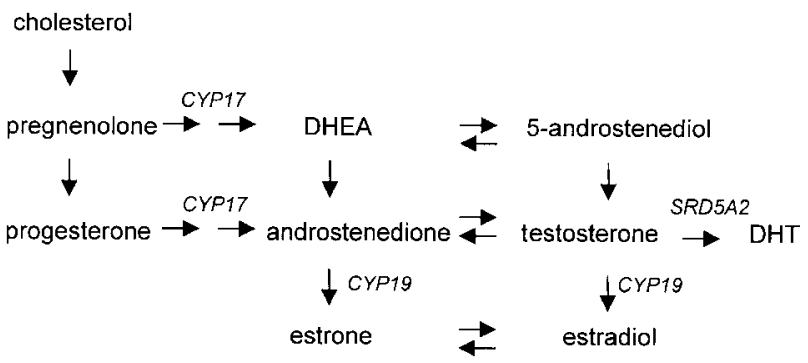

Figure 1 Biosynthesis and metabolism of androgens. DHEA, dehydroepiandrosterone.

enzyme $5 \alpha$-reductase (Fig. 1). In humans, two $5 \alpha$-reductase isoenzymes have been identified. The type 1 enzyme (encoded by the SRD5A1 gene) is expressed mostly in newborn scalp, skin, hair, and liver, whereas the type 2 enzyme (encoded by the $S R D 5 A 2$ gene) is localized primarily in androgen target tissue, including genital skin and the prostate gland (6).

\section{Androgenic action within the prostate}

Both testosterone and DHT exert their androgenic effects in the prostate through the androgen receptor (AR) protein (Fig. 2). The AR is normally associated with heat shock proteins in an inactive state. Androgen binding induces dissociation from heat shock proteins, hyperphosphorylation, conformational changes, and dimerization of the receptor. The ligand-receptor complex then translocates to the cell nucleus where it binds to specific DNA sequences termed androgenresponsive elements located within the promoters of androgen-responsive genes. In conjunction with ARassociated proteins (AR coactivators (ARA)) and other transcription factors, the $\mathrm{AR}$ is then able to up- or down-regulate the transcription of several genes. In vitro studies have shown that certain AR coactivators, such as ARA54, ARA55, ARA70, ARA160, p160, breast cancer susceptibility gene 1 , amplified in breast cancer 1 (AIB1) and cortisol binding protein can enhance AR transcriptional activity several-fold $(7,8)$.

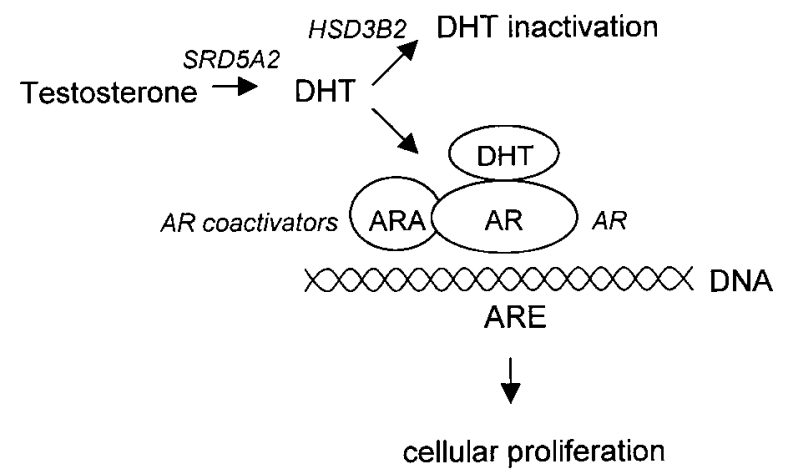

Figure 2 Androgenic action within the prostate.
Activation of the AR leads to complex proliferative, apoptotic, and angiogenic events. Androgens enhance expression of cyclin-dependent kinases 2 and 4 , as well as induce down-regulation of the cell cycle inhibitor p16 (9). The overall effect of androgens in cells expressing AR is an increase of cyclin-dependent kinase activity and stimulation of cells to enter the $S$ phase of the cell cycle, thereby inducing cellular proliferation.

\section{Androgens and prostate cancer}

Androgens play an important role in normal and hyperplastic prostate growth. Both testosterone and DHT have been shown to induce prostate adenocarcinomas in experimental rat models (5). Several epidemiological studies have compared the serum levels of androgens in prostate cancer cases with those in healthy subjects in either case control or prospective designs $(10-21)$. In most of these studies the serum concentrations of testosterone and DHT were measured to assess the role of androgens in prostate cancer. Although only one study reported a statistically significant association between serum levels of testosterone and prostate cancer (16), several studies found a suggestive but statistically non-significant association between prostate cancer and the serum levels of testosterone and DHT $(10,12)$. Circulating testosterone levels in African-American and European-American pregnant women during the first trimester of pregnancy have also been compared (22). African-American women had $47 \%$ higher levels of testosterone, suggesting that in this high-risk population the fetus is exposed to higher concentrations of androgens before birth (22).

In most epidemiological studies the failure to show an association between androgen levels and prostate cancer risk can be partly explained by methodological limitations, including difficulty in making reliable measurements of circulating hormone levels in an epidemiological setting, small sample size, small differences (usually 10-15\%) in mean serum levels of hormones between cases and controls, and large intra- and interassay laboratory variations in serum hormone assays $(2,3,23)$.

The most important limitation in epidemiological studies assessing serum levels of androgens is whether circulating levels of androgens reflect androgenic activity within the prostate gland since the metabolism of testosterone to DHT occurs mainly in the prostate, not in the circulation. If serum levels of androgens do not reflect the levels of DHT in tissue, it is difficult to interpret results from serological studies $(2,3)$. However, no epidemiological studies have investigated levels of hormones in prostate tissue. It is also unclear as to whether cumulative exposure to androgens over a lifetime or exposure at certain points in life is more relevant in prostate carcinogenesis $(2,3)$. 


\section{Genetic polymorphisms}

The search for genetic markers of disease susceptibility often focuses on a gene, based on the properties and metabolic pathways of its protein product. Thus, genes involved in androgen biosynthesis and metabolism cascade have been identified as possible modifiers for prostate cancer (24). Racial differences in genetic polymorphisms that have a role in the metabolism of testosterone and other androgens may partly account for racial differences in prostate cancer risk. Several candidate genes are discussed in this review.

\section{CYP17}

CYP17 is located on chromosome 10 (10q24.32) and encodes the cytochrome P450c17 $\alpha$ enzyme (25). This cytochrome mediates both $17 \alpha$-hydroxylase and 17,20-lyase activities at key points in the testosterone biosynthesis in gonads and adrenals (25). The $5^{\prime}$ untranslated promoter region of the CYP17 gene contains a polymorphic $\mathrm{T}$ to $\mathrm{C}$ substitution that gives rise to A1 (T) and A2 (C) alleles (26). An early study suggested that the A2 allele creates an additional Sp1-binding site (CCACC box) in the CYP17 promoter region (26). Subsequently, Nedelcheva Kristensen et al. (27) did not document Sp1 binding at this polymorphic site or within the promoter region of CYP17 in general, while Lin et al. (28) found that Sp1 is an essential factor for CYP17 transcription in human adrenal NCI-H295A cells. Overall, evidence that the A2 allele increases androgen levels is weak and inconsistent (29-31).

Molecular epidemiological studies have presented contradictory results concerning a potential role of CYP17 in prostate cancer (Table 1). Some studies have indicated that the A2 allele may be associated with an increased risk of prostate cancer (31-36). However, other investigations have been apparently inconclusive $(37,38)$ or have even reported that the A1 allele may increase the risk of prostate cancer $(39,40)$. A recent meta-analysis suggests that the CYP17 polymorphism is unlikely to increase considerably the risk of sporadic prostate cancer on a wide population basis, especially in subjects of European descent (41).

\section{SRD5A2}

SRD5A2 is located on chromosome 2 (2p23) and encodes the steroid $5 \alpha$-reductase type 2 enzyme. This membrane-bound enzyme catalyzes the irreversible conversion of testosterone into the main prostatic androgen, DHT. The binding affinity of DHT to the prostatic AR is five times higher than that of testosterone (42). Ross et al. (43) demonstrated that young Japanese men have lower $5 \alpha$-reductase activity than young Caucasian-American and African-American men. Similarly, Wu et al. (44) reported that the DHT to testosterone ratio was highest in African-Americans, intermediate in whites, and lowest in Asian-Americans, corresponding to the respective risk of developing prostate cancer in these groups.

Certain SRD 5A2 polymorphisms may encode for $5 \alpha$ reductase enzyme variants with different activities, probably due to altered mRNA stability (45). Makridakis et al. (46) reported a missense substitution in the SRD5A2 gene, which replaces valine at codon 89 with leucine (V89L). This substitution results in an almost $30 \%$ reduction in $5 \alpha$-reductase activity both in vitro and in vivo (46). In another variant of the SRD5A2 gene (47), an alanine residue at codon 49 is replaced with threonine (A49T). This missense mutation increases steroid $5 \alpha$-reductase activity fivefold in vitro (47). Thus, these polymorphisms might alter DHT levels and consequently the risk of prostate cancer. A polymorphism in the $3^{\prime}$ untranslated region has also been reported, with different numbers of TA dinucleotide repeats (48). A substitution of glutamine for arginine at codon 227 (R227Q) is already known but is very rare in Asian descent subjects where this polymorphism has been studied (49). The biochemical evidence for a putative relationship of SRD5A2 polymorphisms with androgen levels is controversial (30, 49-51).

Molecular epidemiological studies have presented seemingly contradictory results concerning a potential role of the V89L $(35-37,49,50,52-55)$, A49T (36, $37,47,49,54-56)$ and TA repeat $(37,49,55,57)$ polymorphisms in prostate cancer susceptibility (Table 1). A meta-analysis has excluded a role for the V89L polymorphism in conferring susceptibility to prostate cancer and suggests that the A49T and TA repeat polymorphisms may have a modest effect on prostate cancer susceptibility, but bias and chance findings cannot be excluded (58). The only study investigating the role of the $\mathrm{R} 227 \mathrm{Q}$ polymorphism found no association with prostate cancer risk (49).

\section{$\boldsymbol{A R}$}

The AR is expressed in all histologic types and stages of prostate cancer. The $A R$ gene, which is located on the $\mathrm{X}$ chromosome (Xq11.2-12), is highly polymorphic. Two CAG (coding for polyglutamine) and GGN (coding for glycine) microsatellite repeats are present in exon 1 of the $A R$ gene, residing in the transactivation domain. Expansion of the CAG repeat length in the AR $\mathrm{N}$-terminal region results in a structurally altered protein with reduced transcriptional activity $(59,60)$. An alternative molecular mechanism was raised by Choong et al. (61) who observed that CAG repeat expansion in the first exon of the $A R$ gene reduced AR mRNA and protein levels. However, the biological role of GGN trinucleotide repeats is less clear.

Several reports $(37,62-80)$ have investigated the role of CAG and GGN repeats in predisposition to 
Table 1 Studies of polymorphisms in androgen-related genes and prostate cancer risk.

\begin{tabular}{|c|c|c|c|c|c|c|c|}
\hline \multirow[b]{2}{*}{ Gene } & \multirow[b]{2}{*}{ Polymorphism } & \multirow[b]{2}{*}{ Study (Reference) } & \multirow[b]{2}{*}{ Racial descent } & \multicolumn{2}{|c|}{ Eligible subjects (no.) } & \multicolumn{2}{|r|}{ Results } \\
\hline & & & & Prostate cancer & Controls & Contrast & OR $(95 \% \mathrm{Cl})$ \\
\hline CYP17 & MspAl & $\begin{array}{l}\text { Lunn et al. } 1999 \text { (35) } \\
\text { Wadelius et al. } 1999 \text { (39) } \\
\text { Gsur et al. } 2000(33) \\
\text { Habuchi et al. } 2000 \text { (40) } \\
\text { Haiman et al. } 2001(31) \\
\text { Kittles et al. } 2001(32) \\
\text { Yamada et al. } 2001 \text { (36) } \\
\text { Chang et al. } 2001 \text { (38) } \\
\text { Latil et al. } 2001 \text { (37) } \\
\text { Standford et al. } 2002 \text { (34) }\end{array}$ & $\begin{array}{l}\text { European, African } \\
\text { European } \\
\text { European } \\
\text { Asian } \\
\text { European } \\
\text { African } \\
\text { Asian } \\
\text { European } \\
\text { European } \\
\text { European, African }\end{array}$ & $\begin{array}{r}108 \\
178 \\
63 \\
252 \\
600 \\
71 \\
105 \\
225 \\
226 \\
590\end{array}$ & $\begin{array}{l}167 \\
160 \\
126 \\
333 \\
804 \\
111 \\
210 \\
182 \\
156 \\
538\end{array}$ & $\begin{array}{l}A 2 A 2 \text { vs } A 1 A 1 \\
A 1 A 1 \text { vs } A 2 A 2 \\
A 2 A 2 \text { vs } A 1 A 1 \\
A 1 A 1 \text { vs } A 2 A 2 \\
A 2 A 2 \text { vs } A 1 A 1 \\
A 2 A 2 \text { vs } A 1 A 1 \\
A 2 A 2 \text { vs } A 1 A 1 \\
A 2 A 2 \text { vs } A 1 A 1 \\
A 2 A 2 \text { vs } A 1 A 1 \\
A 2 A 2 \text { vs } A 1 A 1\end{array}$ & $\begin{array}{l}1.70(0.70-4.10) \\
1.61(1.02-2.53) \\
2.80(1.02-7.76) \\
2.57(1.39-4.78) \\
1.17(0.85-1.61) \\
2.80(1.00-7.40) \\
2.39(1.04-5.46) \\
1.04(0.57-1.91) \\
0.94(0.50-1.76) \\
0.87(0.61-1.26)\end{array}$ \\
\hline \multirow[t]{3}{*}{ SRD5A2 } & V89L & $\begin{array}{l}\text { Febbo et al. } 1999(50) \\
\text { Lunn et al. } 1999(35) \\
\text { Margiotti et al. } 2000(55) \\
\text { Nam et al. } 2001(52) \\
\text { Latil et al. } 2001(37) \\
\text { Yamada et al. } 2001(36) \\
\text { Hsing et al. } 2001(49) \\
\text { Pearce et al. } 2002(53) \\
\text { Soderstrom et al. } 2002(54)\end{array}$ & $\begin{array}{l}\text { European } \\
\text { European, African } \\
\text { European } \\
\text { European } \\
\text { European } \\
\text { Asian } \\
\text { Asian } \\
\text { European, Asian, African } \\
\text { European }\end{array}$ & $\begin{array}{l}592 \\
108 \\
108 \\
158 \\
226 \\
105 \\
268 \\
921 \\
176\end{array}$ & $\begin{array}{r}807 \\
167 \\
121 \\
162 \\
156 \\
210 \\
495 \\
1294 \\
161\end{array}$ & $\begin{array}{l}\text { LL vs VV } \\
\text { LL vs VV } \\
\text { VV/VL vs LL } \\
\text { VV vs LL } \\
\text { LL vs VV } \\
\text { LL vs VV } \\
\text { LL vs VV } \\
\text { LL vs VV } \\
\text { VV vs LL }\end{array}$ & $\begin{array}{l}0.84(0.57-1.24) \\
1.00(0.30-2.90) \\
0.35(0.09-1.32) \\
2.76(1.17-6.50) \\
2.30(0.98-5.40) \\
1.37(0.70-2.71) \\
0.88(0.53-1.47) \\
1.15(0.85-1.54) \\
1.42(0.70-2.89)\end{array}$ \\
\hline & A49T & $\begin{array}{l}\text { Makridakis et al. } 1999 \text { (47) } \\
\text { Margiotti et al. } 2000(55) \\
\text { Latil et al. } 2001 \text { (37) } \\
\text { Mononen et al. } 2001 \text { (56) } \\
\text { Yamada et al. } 2001 \text { (36) } \\
\text { Hsing et al. } 2001 \text { (49) } \\
\text { Soderstrom et al. } 2002 \text { (54) }\end{array}$ & $\begin{array}{l}\text { European, African } \\
\text { European } \\
\text { European } \\
\text { European } \\
\text { Asian } \\
\text { Asian } \\
\text { European }\end{array}$ & $\begin{array}{l}388 \\
\\
108 \\
226 \\
449 \\
105 \\
268 \\
176\end{array}$ & $\begin{array}{l}461 \\
\\
121 \\
156 \\
811 \\
210 \\
495 \\
161\end{array}$ & $\begin{array}{ll}\text { AT/TT vs AA } \\
\\
\text { AT vs AA } & \\
\text { AT vs AA } & \\
\text { TT vs AA } & \\
& \text { No } \\
& \text { No } \\
\text { AT vs AA } & \end{array}$ & $\begin{array}{l}\text { European: } 2.50(0.90-7.40) \\
\text { African: } 3.28(1.90-11.87) \\
7.7(0.39-150.54) \\
0.80(0.26-2.42) \\
1.04(0.62-1.76) \\
\text { ele was identified } \\
\text { ele was identified } \\
1.29(0.40-4.15)\end{array}$ \\
\hline & $(\mathrm{TA}) \mathrm{n}$ & $\begin{array}{l}\text { Kantoff et al. } 1997(57) \\
\text { Margiotti et al. } 2000(55) \\
\text { Latil et al. } 2001(37) \\
\text { Hsing et al. } 2001 \text { (49) }\end{array}$ & $\begin{array}{l}\text { European } \\
\text { European } \\
\text { European } \\
\text { Asian }\end{array}$ & $\begin{array}{l}590 \\
108 \\
226 \\
268\end{array}$ & $\begin{array}{l}802 \\
121 \\
156 \\
495\end{array}$ & $\begin{array}{l}\text { LL vs SS } \\
\text { SL/LL vs SS } \\
\text { LL vs SS } \\
\text { LL vs SS }\end{array}$ & $\begin{array}{l}0.47(0.20-1.12) \\
0.95(0.51-1.72) \\
0.50(0.11-2.26) \\
0.74(0.07-8.31)\end{array}$ \\
\hline$A R$ & $\begin{array}{l}\text { R227Q } \\
(C A G) n\end{array}$ & $\begin{array}{l}\text { Hsing et al. } 2001(49) \\
\text { Irvine et al. } 1995 \text { (70) } \\
\text { Ingles et al. } 1997(66) \\
\text { Stanford et al. } 1997(68) \\
\text { Giovannucci et al. 1997 (67) } \\
\text { Ekman et al. } 1999(78) \\
\text { Edwards et al. } 1999(73) \\
\text { Correa-Cerro et al. } 1999(74) \\
\text { Bratt et al. } 1999 \text { (77) }\end{array}$ & $\begin{array}{l}\text { Asian } \\
\text { European, Asian, African } \\
\text { European } \\
\text { European } \\
\text { European } \\
\text { European, Asian } \\
\text { European } \\
\text { European } \\
\text { European }\end{array}$ & $\begin{array}{r}268 \\
68 \\
57 \\
301 \\
587 \\
59 \\
178 \\
132 \\
160\end{array}$ & $\begin{array}{r}495 \\
123 \\
169 \\
277 \\
588 \\
38 \\
195 \\
105 \\
186 \\
186\end{array}$ & $\begin{array}{l}\text { RQ vs } R R \\
<22 \text { vs } 22 \\
<20 \text { vs } 20 \\
<22 \text { vs } 22 \\
18 \text { vs } 26 \\
<15 \text { vs } 15 \\
21 \text { vs }>21 \\
<22 \text { vs } 22 \\
\text { A shorter repe } \\
\text { age at diagno }\end{array}$ & $\begin{array}{l}2.85(0.25-32.1) \\
1.25(0.54-2.92) \\
2.10(1.11-3.99) \\
1.23(0.88-1.73) \\
2.14(1.14-4.01) \\
1.10(0.43-2.84) \\
1.00(0.96-1.03) \\
1.20(0.70-2.00) \\
\text { las associated with younger } \\
\text { and higher grade and stage }\end{array}$ \\
\hline
\end{tabular}


Table 1. Continued

\begin{tabular}{|c|c|c|c|c|c|c|c|}
\hline \multirow[b]{2}{*}{ Gene } & \multirow[b]{2}{*}{ Polymorphism } & \multirow[b]{2}{*}{ Study (Reference) } & \multirow[b]{2}{*}{ Racial descent } & \multicolumn{2}{|c|}{ Eligible subjects (no.) } & \multicolumn{2}{|r|}{ Results } \\
\hline & & & & Prostate cancer & Controls & Contrast & OR $(95 \% \mathrm{Cl})$ \\
\hline & & Hsing et al. 2000 (69) & Asian & 190 & 304 & $<23$ vs 23 & $1.65(1.14-2.39)$ \\
\hline & & Latil et al. 2001 (37) & European & 226 & 156 & 20 vs $>24$ & $1.10(0.60-2.02)$ \\
\hline & & Beilin et al. 2001 (76) & European & 545 & 456 & Every 5 repeats & $0.98(0.84-1.15)$ \\
\hline & & Panz et al. 2001 (64) & European, African & 40 & 40 & \multicolumn{2}{|c|}{$\begin{array}{l}\text { Cases had a shorter repeat length than controls } \\
\text { (20 vs } 23 \text { ) }\end{array}$} \\
\hline & & Modugno et al. 2001 (65) & European & 449 & 558 & $<23$ vs 23 & $1.75(1.05-2.95)$ \\
\hline & & Mononen et al. 2002 (63) & European & 461 & 574 & 18 vs $>18$ & $1.47(1.00-2.16)$ \\
\hline & & Chen et al. 2002 (71) & European & 300 & 300 & $<22$ vs 22 & $0.89(0.65-1.23)$ \\
\hline & & Chang et al. 2002 (72) & European, African & 245 & 211 & 21 vs 22 & $0.82(0.55-1.22)$ \\
\hline & & Gsur et al. 2002 (75) & European & 190 & 190 & 23 vs 20 & $1.07(0.67-1.73)$ \\
\hline & $(G G N) n$ & Irvine et al. 1995 (70) & European, Asian, African & 68 & 123 & Non- 16 vs 16 & 1.18 \\
\hline & & Stanford et al. 1997 (68) & European & 301 & 277 & 16 vs $>16$ & $1.60(1.07-2.41)$ \\
\hline & & Platz et al. 1998 (80) & European & 582 & 794 & 23 vs Non-23 & $1.20(0.97-1.49)$ \\
\hline & & Edwards et al. 1999 (73) & European & 178 & 195 & 16 vs $>16$ & $1.06(0.70-1.76)$ \\
\hline & & Correa-Cerro et al. 1999 (74) & European & 132 & 105 & Every 1 repeat & $1.00(0.90-1.10)$ \\
\hline & & Hsing et al. 2000 (69) & Asian & 190 & 304 & 16 vs $>16$ & $1.12(0.71-1.78)$ \\
\hline & & Chen et al. 2002 (71) & European & 300 & 300 & 17 vs $>17$ & $0.80(0.57-1.12)$ \\
\hline$A \mid B I$ & $(\mathrm{CAG}) \mathrm{n}$ & Platz et al. 2000 (85) & European & 581 & 786 & $28 / 28$ vs $28 / 29$ & $1.10(0.79-1.53)$ \\
\hline & & Hsing et al. 2002 (84) & Asian & 189 & 299 & $28 / 28$ vs $29 / 29$ & $2.12(1.09-4.12)$ \\
\hline \multirow{2}{*}{ CYP19 } & (TTTA)n & Latil et al. 2001 (37) & European & 226 & 156 & $187 \mathrm{bp}$ vs $167 \mathrm{bp}$ & $1.41(1.01-1.98)$ \\
\hline & Arg264Cys & Modugno et al. 2001 (65) & European & 88 & 241 & CT vs CC & $1.72(0.72-4.08)$ \\
\hline \multicolumn{8}{|c|}{ 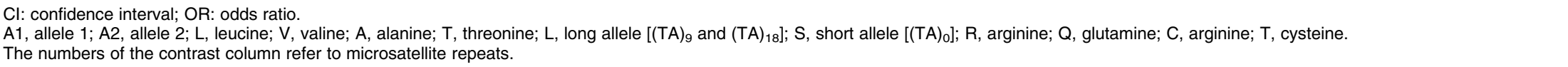 } \\
\hline
\end{tabular}


prostate cancer and have produced inconsistent results (Table 1). Shorter alleles of the CAG repeat seem to be associated with a modest increase in prostate cancer risk (62-70). Other studies, however, reported no association, or a weak and not statistically significant association, between shorter CAG repeat alleles and prostate cancer $(37,71-79)$. Interestingly, the frequency distribution of the $A R$ gene CAG repeat length varies among different racial/ethnic groups. Shorter alleles are found more frequently in African-American men who have a higher incidence of prostate cancer. Conversely, populations at lower risk of prostate cancer (Caucasians and Asians) exhibit a relatively high number of CAG repeats $(70,81)$. The role of the GGN trinucleotide repeat in prostate cancer predisposition is also controversial $(68-74,80)$.

Two additional $A R$ gene polymorphisms have been investigated for their association with prostate cancer: the R726L (a substitution of leucine for arginine at codon 726) in exon 5 and the G1733A single nucleotide polymorphism, designated the S1 and S2 alleles, which correspond to the absence and presence respectively of a diagnostic cleavage site for the Stu I restriction endonuclease. The R726L polymorphism, which alters the transactivational specificity of the AR protein, has been associated with an almost sixfold increased prostate cancer risk in Finnish men (82). The S1 Stu I allele was shown to be associated with a threefold higher prostate cancer risk among African-American men under the age of 65 years (83).

\section{AR coactivators}

The AIB1 gene has two distinct CAG trinucleotide repeats. Two studies have investigated the role of AIB1 in prostate cancer: one found a positive association between AIB1 CAG repeat length and prostate cancer (84), and the other reported no association (85) (Table 1). Future studies are needed to investigate the effect of AR coactivators in prostate cancer risk.

\section{HSD3B2}

Inactivation of DHT in the prostate is an important determinant of intracellular DHT concentration and a potential modulator of androgenic activity in the prostate gland. Incomplete inactivation or slower degradation of DHT within the prostate can lead to the accumulation of DHT and, perhaps, increased androgenic action. Thus, enzymes that inactivate DHT may play a role in predisposition to prostate cancer. HSD 3B2 is located on chromosome 1 (1p13.1) and encodes the $3 \beta$-hydroxysteroid dehydrogenase type 2 enzyme that initiates the irreversible inactivation of DHT within the prostate. A complex dinucleotide repeat polymorphism has been reported in the third intron of the HSD3B2 gene (86). Devgan et al. (87) examined the distribution of the (TG)n(TA)n(CA)n repeat in the $H S D 3 B 2$ gene in high-risk African descent subjects, intermediate-risk European descent subjects, and low-risk Asian descent subjects. A total of 25 different alleles were identified, of which the $289 \mathrm{bp}$ allele was the most common allele in all population groups. Interestingly, a $275 \mathrm{bp}$ allele was significantly more common among African-American men, a $340 \mathrm{bp}$ allele among European-American men and a $281 \mathrm{bp}$ allele and alleles ranging from 302 to $334 \mathrm{bp}$ were found to be significantly more common among Asian men. However, functional effects of the different alleles have not yet been reported and no studies have elucidated prostate cancer risk associated with a particular allele.

\section{CYP19}

The CYP19 gene is located on chromosome 15 (15q21.1) and encodes the enzyme aromatase that catalyzes the irreversible conversion of androstenedione to estrone and testosterone to estradiol. Aromatase is present in the gonads and in the extragonadal tissue, including the prostate and adipose tissue. Aromatase mRNA and protein have both been detected in benign prostatic hyperplasia (BPH) and prostate cancer tissue $(88,89)$. Two studies have investigated the role of CYP19 in prostate cancer $(37,65)$ (Table 1). One study found a positive association with the tetranucleotide repeat (TTTA)n in intron 4 of the CYP19 gene (37), and the other reported that Arg264Cys polymorphism (a $\mathrm{C}$ to $\mathrm{T}$ substitution in exon 7 ) was associated with a non-significant increase in the risk of prostate cancer $(65)$.

\section{Conclusions}

Despite the evidence linking androgens and prostate cancer, molecular epidemiological studies have yielded conflicting results. Postulated genetic associations for prostate cancer need to be carefully validated across several studies, since early and small genetic association studies may come up with spurious findings (90). A very large number of subjects is needed to establish or refute a genetic association of modest magnitude and even larger numbers are needed to validate subgroup differences, let alone more subtle associations such as gene-gene and gene-environment interactions. Furthermore, genetic associations for such a multigenetic disease are likely to have relatively small odds ratios requiring large sample sizes to clarify the association.

Some other limitations of genetic association studies should be acknowledged. First, prostate cancer is very common and thus some non-differential misclassification bias is possible. The majority of the considered studies could not exclude latent prostate cancer cases in the control group and some young control subjects 
may have developed prostate cancer during the subsequent years. The choice of an appropriate age window for assessing a postulated genetic risk factor for prostate cancer is difficult. Studies of younger subjects may be more suitable for identifying risk factors that result in early carcinogenesis. Conversely, selection of younger subjects may be less appropriate if hormonal or other influences regulated by the postulated risk factor are more important in later ages. Second, control groups included a large, often unknown proportion of subjects with BPH. BPH may also be androgen dependent and affected by these same polymorphisms. Third, genetic association studies can suffer from publication bias; null studies are much less likely to be submitted or to be accepted for publication.

Most current genetic association studies investigate common polymorphisms in specific genes without considering the functional consequences of these polymorphisms, making the results of such studies difficult to interpret $(2,3)$. For example, a particular association between a specific genetic marker and prostate cancer risk may be significant by chance or due to multiple comparisons. Furthermore, a postulated association may merely reflect linkage disequilibrium of the genetic polymorphism to another truly causative marker $(2,3)$.

Finally, the prevalence of prostate cancer in the population probably results from complex interactions among many genetic and environmental factors. Cumulative lifetime exposure to androgens, as well as environmental exposures, could play an important role in the development of prostate cancer in genetically predisposed men. It is likely that a set of genetic polymorphisms rather than a single polymorphism can alter hormone levels and prostate cancer risk. The development of a polygenic model for prostate cancer incorporating multiple loci from the individual genes may yield better preventive, diagnostic, and therapeutic strategies.

\section{References}

1 Hsing AW, Tsao L \& Devesa SS. International trends and patterns of prostate cancer incidence and mortality. International Journal of Cancer $2000 \mathbf{8 5}$ 60-67.

2 Hsing AW. Hormones and prostate cancer: what's next? Epidemiologic Reviews 200123 42-58.

3 Hsing AW, Reichardt JK \& Stanczyk FZ. Hormones and prostate cancer: current perspectives and future directions. Prostate $200252213-235$.

4 Richie JP. Anti-androgens and other hormonal therapies for prostate cancer. Urology $1999 \mathbf{5 4}$ (Suppl 6A) 15-18.

5 Noble RL. The development of prostatic adenocarcinoma in $\mathrm{Nb}$ rats following prolonged sex hormone administration. Cancer Research 197737 1929-1933.

6 Thigpen AE, Silver RI, Guileyardo JM, Casey ML, McConnell JD \& Russell DW. Tissue distribution and ontogeny of steroid $5 \alpha$-reductase isozyme expression. Journal of Clinical Investigation 199392 903-910.
7 Yeh S \& Chang C. Cloning and characterization of a specific coactivator, ARA70, for the androgen receptor in human prostate cells. PNAS 199693 5517-5521.

8 Park JJ, Irvine RA, Buchanan G, Koh SS, Park JM, Tilley WD et al. Breast cancer susceptibility gene 1 (BRCAI) is a coactivator of the androgen receptor. Cancer Research 200060 5946-5949.

$9 \mathrm{Lu} \mathrm{S}$, Tsai SY \& Tsai MJ. Regulation of androgen-dependent prostatic cancer cell growth: androgen regulation of CDK2, CDK4, and CKI p16 genes. Cancer Research 199757 4111-4116.

10 Nomura AM, Heilbrun LK, Stemmermann GN \& Judd HL. Prediagnostic serum hormones and the risk of prostate cancer. Cancer Research $1988 \mathbf{4 8} 3515-3517$.

11 Barrett-Conor E, Garland C, McPhillips JB, Khaw KT \& Wingard DL. A prospective, population-based study of androstenedione, estrogens, and prostatic cancer. Cancer Research $1990 \mathbf{5 0}$ 169-173.

12 Hsing AW \& Comstock GW. Serological precursors of cancer: serum hormones and risk of subsequent prostate cancer. Cancer Epidemiology, Biomarkers and Prevention 19932 27-32.

13 Comstock GW, Gordon G \& Hsing AW. The relationship of serum dehydroepiandrosterone and its sulfate to subsequent cancer of the prostate. Cancer Epidemiology, Biomarkers and Prevention 19932 219-221.

14 Carter HB, Pearson JD, Metter EJ, Chan DW, Andres R, Fozard JL et al. Longitudinal evaluation of serum androgen levels in men with and without prostate cancer. Prostate 199527 25-31.

15 Nomura AM, Stemmermann GN, Chyou PH, Henderson BE \& Stanczyk FZ. Androgens and prostate cancer. Cancer Epidemiology, Biomarkers and Prevention 19965 621-625.

16 Gann PH, Hennekens CH, Ma J, Longcope C \& Stampfer MJ. Prospective study of sex hormone levels and risk of prostate cancer. Journal of the National Cancer Institute $1996 \mathbf{8 8} 1118-1126$.

17 Guess HA, Friedman GD, Sadler MC, Stanczyk FZ, Vogelman JH, Imperato-McGinley J et al. 5 alpha-reductase activity and prostate cancer: a case-control study using stored sera. Cancer Epidemiology, Biomarkers and Prevention 19976 21-24.

18 Vatten LJ, Ursin G, Ross RK, Stanczyk FZ, Lobo RA, Harvei S et al. Androgens in serum and the risk of prostate cancer: a nested case-control study from the Janus serum bank in Norway. Cancer Epidemiology, Biomarkers and Prevention $19976967-969$.

19 Dorgan JF, Albanes D, Virtamo J, Heinonen OP, Chandler DW, Galmarini $\mathrm{M}$ et al. Relationships of serum androgens and estrogens to prostate cancer risk: results from a prospective study in Finland. Cancer Epidemiology, Biomarkers and Prevention 19987 1069-1074.

20 Heikkila R, Aho K, Heliovaara M, Hakama M, Marniemi J, Reunanen A et al. Serum testosterone and sex hormone-binding globulin concentrations and the risk of prostate carcinoma: a longitudinal study. Cancer 199986 312-315.

21 Mohr BA, Feldman HA, Kalish LA, Longcope C \& McKinlay JB. Are serum hormones associated with the risk of prostate cancer? Prospective results from the Massachusetts Male Aging Study. Urology $2001 \mathbf{5 7}$ 930-935.

22 Henderson BE, Bernstein L, Ross RK, Depue RH \& Judd HL. The early in utero estrogen and testosterone environment of blacks and whites: potential effects on male offspring. British Journal of Cancer 198857 216-218.

23 Fears TR, Ziegler RG, Donaldson JL, Falk RT, Hoover RN, Stanczyk FZ et al. Reproducibility studies and interlaboratory concordance for androgen assays in female plasma. Cancer Epidemiology, Biomarkers and Prevention 2000 9 403-412.

24 Makridakis NM \& Reichardt JK. Molecular epidemiology of hormone-metabolic loci in prostate cancer. Epidemiologic Reviews $20012324-29$.

25 Picado-Leonard J \& Miller WL. Cloning and sequence of the human gene for P450c17 (steroid 17 alpha-hydroxylase/17,20 lyase): similarity with the gene for P450c21. DNA 19876 439-448.

26 Carey AH, Waterworth D, Patel K, White D, Little J, Novelli P et al. Polycystic ovaries and premature male pattern baldness are 
associated with one allele of the steroid metabolism gene CYP17. Human Molecular Genetics 19943 1873-1876.

27 Nedelcheva Kristensen V, Haraldsen EK, Anderson KB, Lonning PE, Erikstein B, Karesen R et al. CYP17 and breast cancer risk: the polymorphism in the $5^{\prime}$ flanking area of the gene does not influence binding to Sp-1. Cancer Research 199959 2825-2828.

28 Lin CJ, Martens JW \& Miller WL. NF-1C, Sp1, and Sp3 are essential for transcription of the human gene for P450c17 (steroid 17alpha-hydroxylase/17,20 lyase) in human adrenal NCIH295A cells. Molecular Endocrinology 200115 1277-1293.

29 Zmuda JM, Cauley JA, Kuller LH \& Ferrell RE. A common promotor variant in the cytochrome P450c17alpha (CYP17) gene is associated with bioavailability testosterone levels and bone size in men. Journal of Bone and Mineral Research $200116911-917$.

30 Allen NE, Forrest MS \& Key TJ. The association between polymorphisms in the CYP17 and 5alpha-reductase (SRD5A2) genes and serum androgen concentrations in men. Cancer Epidemiology, Biomarkers and Prevention 200110 185-189.

31 Haiman CA, Stampfer MJ, Giovannuci E, Ma J, Decalo NE, Kantoff PW et al. The relationship between a polymorphism in CYP17 with plasma hormone levels and prostate cancer. Cancer Epidemiology, Biomarkers and Prevention 200110 743-748.

32 Kittles RA, Panguluri RK, Chen W, Massac A, Ahaghotu C, Jackson A et al. Cyp17 promoter variant associated with prostate cancer aggressiveness in African Americans. Cancer Epidemiology, Biomarkers and Prevention 200110 943-947.

33 Gsur A, Bernhofer G, Hinteregger S, Haidinger G, Schatzl G, Madersbacher S et al. A polymorphism in the CYP17 gene is associated with prostate cancer risk. International Journal of Cancer 200087 434-437.

34 Stanford JL, Noonan EA, Iwasaki L, Kolb S, Chadwick RB, Feng Z et al. A polymorphism in the CYP17 gene and risk of prostate cancer. Cancer Epidemiology, Biomarkers and Prevention 200211 243-247.

35 Lunn RM, Bell DA, Mohler JL \& Taylor JA. Prostate cancer risk and polymorphism in 17 hydroxylase (CYP17) and steroid reductase (SRD5A2). Carcinogenesis 199920 1727-1731.

36 Yamada Y, Watanabe M, Murata M, Yamanaka M, Kubota Y, Ito H et al. Impact of genetic polymorphisms of 17-hydroxylase cytochrome P-450 (CYP-17) and steroid 5alpha-reductase type II (SRD5A2) genes on prostate-cancer risk among the Japanese population. International Journal of Cancer 200192 683-686.

37 Latil AG, Azzouzi R, Cancel GS, Guillaume EC, Cochan-Priollet B, Berthon PL et al. Prostate carcinoma risk and allelic variants of genes involved in androgen biosynthesis and metabolism pathways. Cancer 200192 1130-1137.

38 Chang BI, Zheng SL, Issacs SD, Wiley KE, Carpten JD, Hawkins GA et al. Linkage and association of CYP17 gene in hereditary and sporadic prostate cancer. International Journal of Cancer 200195 354-359.

39 Wadelius M, Andersson AO, Johansson JE, Wadelius C \& Rane E. Prostate cancer associated with CYP17 genotype. Pharmacogenetics $19999635-639$.

40 Habuchi T, Liqing Z, Suzuki T, Sasaki R, Tsuchiya N, Tachiki H et al. Increased risk of prostate cancer and benign prostatic hyperplasia associated with a CYP17 gene polymorphism with a gene dosage effect. Cancer Research 200060 5710-5713.

41 Ntais C, Polycarpou A \& Ioannidis JP. Association between CYP17 gene polymorphism with the risk of prostate cancer: a meta-analysis. Cancer Epidemiology, Biomarkers and Prevention 200312 120-126.

42 Wilbert DM, Griffin JE \& Wilson JD. Characterization of the cytosol androgen receptor of the human prostate. Journal of Clinical Endocrinology and Metabolism 198356 113-120.

43 Ross RK, Bernstein L, Lobo RA, Shimizu FZ, Stanczyk FZ, Pike MC et al. $5 \alpha$-Reductase activity and risk of prostate cancer among Japanese and US white and black males. Lancet 1992339 887-889.

44 Wu AH, Whittemore AS, Kolonel LN, John EM, Gallagher RP, West DW et al. Serum androgens and sex-hormone binding globulins in relation to lifestyle factors in older African-American, white, and Asian men in the United States and Canada. Cancer Epidemiology, Biomarkers and Prevention 19954 735-741.

45 Reichardt JK, Makridakis N, Henderson BE, Yu MC, Pike MC \& Ross RK. Genetic variability of the human SRD5A2 gene: implications for prostate cancer risk. Cancer Research $1995 \mathbf{5 5}$ 3973-3975.

46 Makridakis N, Ross RK, Pike MC, Chang PL, Stanczyk FZ, Kolonel LN et al. A prevalent missense substitution that modulates activity of prostatic steroid $5 \alpha$-reductase. Cancer Research 199757 1020-1022.

47 Makridakis NM, Ross RK, Pike MC, Crocitto LE, Kolonel LN, Pearce CL et al. Association of mis-sense substitution in SRD5A2 gene with prostate cancer in African-American and Hispanic men in Los Angeles, USA. Lancet $19993 \mathbf{5 4} 975-978$.

48 Davis DL \& Russell DW. Unusual length polymorphism in human steroid 5-alpha-reductase type 2 gene (SRD5A2). Human Molecular Genetics 19932820.

49 Hsing AW, Chen C, Chokkalingam AP, Gao YT, Dightman DA, Nguyen HT et al. Polymorphic markers in the SRD5A2 gene and prostate cancer risk: a population-based case-control study. Cancer Epidemiology, Biomarkers and Prevention $2001 \quad 10$ 1077-1082.

50 Febbo PG, Kantoff PW, Platz EA, Casey D, Batter S, Giovannucci E et al. The V89L polymorphism in the $5 \alpha$-reductase type 2 gene and risk of prostate cancer. Cancer Research $1999 \quad 59$ 5878-5881.

51 Schatzl G, Madersbacher S, Gsur A, Preyer M, Haidinger G, Haitel A et al. Association of polymorphisms within androgen receptor, 5alpha-reductase, and PSA genes with prostate volume, clinical parameters, and endocrine status in elderly men. Prostate 200252 130-138.

52 Nam RK, Toi A, Vesprini D, Ho M, Chu W, Harvie S et al. V89L polymorphism of type-2, 5-alpha reductase enzyme gene predicts prostate cancer presence and progression. Urology 200157 199-205.

53 Pearce CL, Makridakis NM, Ross RK, Pike M, Kolonel LN, Henderson BE et al. Steroid 5- $\alpha$ reductase type II V89L substitution is not associated with risk of prostate cancer in a multiethnic population study. Cancer Epidemiology, Biomarkers and Prevention $200211417-418$.

54 Soderstrom T, Wadelius M, Andersson SO, Johansson JE, Johansson S, Granath F et al. $5 \alpha$-reductase 2 polymorphisms as risk factors in prostate cancer. Pharmacogenetics 200212 $307-312$.

55 Margiotti K, Sangiuolo F, De Luca A, Froio F, Pearce CL, Ricci-Barbini $\mathrm{V}$ et al. Evidence for an association between the SRD5A2 (type II steroid $5 \alpha$-reductase) locus and prostate cancer in Italian patients. Disease Markers 200016 147-150.

56 Mononen N, Ikonen T, Syrjakoski K, Matikainen M, Schleutker J, Tammela TL et al. A missense substitution A49T in the steroid 5alpha-reductase gene (SRD5A2) is not associated with prostate cancer in Finland. British Journal of Cancer $2001841344-1347$.

57 Kantoff PW, Febbo PG, Giovannucci E, Krithivas K, Dahl DM, Chang $\mathrm{G}$ et al. A polymorphism of the 5 alpha-reductase gene and its association with prostate cancer: a case-control analysis. Cancer Epidemiology, Biomarkers and Prevention 19976 189-192.

58 Ntais C, Polycarpou A \& Ioannidis JP. SRD5A2 gene polymorphisms and the risk of prostate cancer: a meta-analysis. Cancer Epidemiology, Biomarkers and Prevention 200312 618-624.

59 Chamberlain NL, Driver ED \& Miesfeld RL. The length and location of CAG trinucleotide repeats in the androgen receptor N-terminal domain affect transactivation function. Nucleic Acids Research 199422 3181-3186.

60 Kazemi Esfarjani P, Trifiro MA \& Pinsky L. Evidence for a repressive function of the long polyglutamine tract in the human androgen receptor: possible pathogenic relevance for the (CAG)n-expanded neuropathies. Human Molecular Genetics $19954523-527$. 
61 Choong CS, Kemppainen JA, Zhou ZX \& Wilson EM. Reduced androgen receptor gene expression with first exon CAG repeat expansions. Molecular Endocrinology $1996101527-1535$.

62 Balic I, Graham ST, Troyer DA, Higgins BA, Pollock BH, Johnson-Pais TL et al. Androgen receptor length polymorphism associated with prostate cancer risk in Hispanic men. Journal of Urology $20021682245-2248$.

63 Mononen N, Ikonen T, Autio V, Rokman A, Matikainen MP, Tammela TL et al. Androgen receptor CAG polymorphism and prostate cancer risk. Human Genetics 2002111 166-171.

64 Panz VR, Joffe BI, Spitz I, Lindenberg T, Farkas A \& Haffejee M. Tandem CAG repeats of the androgen receptor gene and prostate cancer risk in black and white men. Endocrine 200115 213-216.

65 Modugno F, Weissfeld JL, Trump DL, Zmuda JM, Shea P, Cauley JA et al. Allelic variants of aromatase and the androgen and estrogen receptors: toward a multigenic model of prostate cancer risk. Clinical Cancer Research $200173092-3096$.

66 Ingles SA, Ross RK, Yu MC, Irvine RA, La Pera G, Haile RW et al. Association of prostate cancer risk with genetic polymorphisms in vitamin D receptor and androgen receptor. Journal of the National Cancer Institute 199789 166-170.

67 Giovannucci E, Stampfer MJ, Krithivas K, Brown M, Dahl D, Brufsky A et al. The CAG repeat within the androgen receptor gene and its relationship to prostate cancer. PNAS $1997 \mathbf{9 4}$ 3320-3323.

68 Stanford JL, Just JJ, Gibbs M, Wicklund KG, Neal CL, Blumenstein BA et al. Polymorphic repeats in the androgen receptor gene: molecular markers of prostate cancer risk. Cancer Research 199757 1194-1198.

69 Hsing AW, Gao YT, Wu G, Wang X, Deng J, Chen YL et al. Polymorphic CAG and GGN repeat lengths in the androgen receptor gene and prostate cancer risk: a population-based case-control study in China. Cancer Research $2000605111-5116$.

70 Irvine RA, Yu MC, Ross RK \& Coetzee GA. The CAG and GGC microsatellites of the androgen receptor gene are in linkage disequilibrium in men with prostate cancer. Cancer Research 1995 55 1937-1940.

71 Chen C, Lamharzi N, Weiss NS, Etzioni R, Dightman DA, Barnett $\mathrm{M}$ et al. Androgen receptor polymorphisms and the incidence of prostate cancer. Cancer Epidemiology, Biomarkers and Prevention 200211 1033-1040.

72 Chang BL, Zheng SL, Hawkins GA, Isaacs SD, Wiley KE, Turner A et al. Polymorphic GGC repeats in the androgen receptor gene are associated with hereditary and sporadic prostate cancer risk. Human Genetics $2002110122-129$.

73 Edwards SM, Badzioch MD, Minter R, Hamoudi R, Collins N, Ardern-Jones A et al. Androgen receptor polymorphisms: association with prostate cancer risk, relapse and overall survival. International Journal of Cancer $1999 \mathbf{8 4} 458-465$.

74 Correa-Cerro L, Wohr G, Haussler J, Berthon P, Drelon E, Mangin $\mathrm{P}$ et al. (CAG)nCAA and GGN repeats in the human androgen receptor gene are not associated with prostate cancer in a French-German population. European Journal of Human Genetics $19997357-362$.

75 Gsur A, Preyer M, Haidinger G, Zidek T, Madersbacher S, Schatzl G et al. Polymorphic CAG repeats in the androgen receptor gene, prostate-specific antigen polymorphism and prostate cancer risk. Carcinogenesis 200223 1647-1651.

76 Beilin J, Harewood L, Frydenberg M, Mameghan H, Martyres RF, Farish SJ et al. A case-control study of the androgen receptor gene
CAG repeat polymorphism in Australian prostate carcinoma subjects. Cancer $200192941-949$.

77 Bratt O, Borg A, Kristoffersson U, Lundgren R, Zhang QX \& Olsson H. CAG repeat length in the androgen receptor gene is related to age at diagnosis of prostate cancer and response to endocrine therapy, but not to prostate cancer risk. British Journal of Cancer $1999 \mathbf{8 1} 672-676$.

78 Ekman P, Gronberg H, Matsuyama H, Kivineva M, Bergerheim US \& Li C. Links between genetic and environmental factors and prostate cancer risk. Prostate 199939 262-268.

79 Lange EM, Chen H, Brierley K, Livermore H, Wojno KJ, Langefeld $\mathrm{CD}$ et al. The polymorphic exon 1 androgen receptor CAG repeat in men with a potential inherited predisposition to prostate cancer. Cancer Epidemiology, Biomarkers and Prevention 20009 439-442.

80 Platz EA, Giovannucci E, Dahl DM, Krithivas K, Hennekens CH, Brown $\mathrm{M}$ et al. The androgen receptor gene GGN microsatellite and prostate cancer risk. Cancer Epidemiology, Biomarkers and Prevention 19987 379-384.

81 Edwards A, Hammond HA, Jin L, Caskey CT \& Chakraborty R. Genetic variation at five trimeric and tetrameric tandem repeat loci in four human population groups. Genomics 199212 241-253.

82 Mononen N, Syrjakoski K, Matikainen M, Tammela TL, Schleutker J, Kallioniemi OP et al. Two percent of Finnish prostate cancer patients have a germ-line mutation in the hormone-binding domain of the androgen receptor gene. Cancer Research 2000 $606479-6481$.

83 Ross RK, Pike MC, Coetzee GA, Reichardt JK, Yu MC, Feigelson H et al. Androgen metabolism and prostate cancer: establishing a model of genetic susceptibility. Cancer Research $1998 \mathbf{5 8}$ 4497-4504.

84 Hsing AW, Chokkalingam AP, Gao YT, Wu G, Wang X, Deng J et al. Polymorphic CAG/CAA repeat length in the AIB1/SRC-3 gene and prostate cancer risk: a population-based case-control study. Cancer Epidemiology, Biomarkers and Prevention 200211 337-341.

85 Platz EA, Giovannucci E, Brown M, Cieluch C, Shepard TF, Stampfer MJ et al. Amplified in breast cancer-1 glutamine repeat and prostate cancer risk. Prostate Journal 20002 27-32.

86 Verreault H, Dufort I, Simard J, Labrie F \& Luu-The V. Dinucleotide repeat polymorphisms in the HSD3B2 gene. Human Molecular Genetics 19943384.

87 Devgan SA, Henderson BE, Yu MC, Shi CY, Pike MC, Ross RK et al. Genetic variation of 3 beta-hydroxysteroid dehydrogenase type II in three racial/ethnic groups: implications for prostate cancer risk. Prostate 199733 9-12.

88 Tsugaya M, Harada N, Tozawa K, Yamada Y, Hayashi Y, Tanaka S et al. Aromatase mRNA levels in benign prostatic hyperplasia and prostate cancer. International Journal of Urology $19963292-296$.

89 Hiramatsu M, Maehara I, Ozaki M, Harada N, Orikasa S \& Sasano H. Aromatase in hyperplasia and carcinoma of the human prostate. Prostate 199731 118-124.

90 Ioannidis JP, Ntzani EE, Trikalinos TA \& Contopoulos-Ioannidis DG. Replication validity of genetic association studies. Nature Genetics 200129 306-309.

Received 14 April 2003

Accepted 6 August 2003 